\title{
Interaction of Calcium Carbonates with Lead in Aqueous Solutions
}

\author{
ATHANASIOS GODELITSAS, ${ }^{*}, \dagger$ \\ JOSE MANUEL ASTILLEROS, † \\ KEITH HALLAM, ‡ \\ SOTIRIOS HARISSOPOULOS, § \\ AND ANDREW PUTNIS†
}

\begin{abstract}
Institut für Mineralogie, Universität Münster, Corrensstrasse 24, D-48149 Münster, Germany, Interface Analysis Centre, University of Bristol, 121 St. Michael's Hill, Bristol BS2 8BS, U.K., and Institute of Nuclear Physics, NRCPS "Demokritos", GR-15310 Attiki, Greece
\end{abstract}

Pure calcium carbonate (calcite and aragonite) solid materials of different particle size (100-200 im fragments and millimeter-sized single crystals) were interacted with $\mathrm{Pb}$ in aqueous solutions at room temperature under atmospheric $P_{\mathrm{CO}_{2}}$. In the case of the micrometer-sized samples, the macroscopic investigation using a batch-type treatment procedure (solutions between 10 and $1000 \mathrm{mg} / \mathrm{L} \mathrm{Pb}$ ) and ICP-AES, SEM-EDS, and powder-XRD showed that the metal is readily removed from the aqueous media by both materials and indicated the sorption processes (mainly surface precipitation leading to overgrowth of cerussite and hydrocerussite crystals) taking place in parallel with surface dissolution processes. The various processes occurring at the calcium carbonate solid-water interface were clearly distinguished and defined in the case of the millimeter-sized samples interacted with $1000 \mathrm{mg} / \mathrm{L} \mathrm{Pb}$ using a combination of wet-chemical, in-situ (AFM) and ex-situ (AFM, SEM) microscopic, and surface spectroscopic (XPS, ${ }^{12} \mathrm{C}-$ RBS) techniques. The in-situ AFM data revealed the dissolution processes on the surface of the calcium carbonates and the simultaneous heterogeneous nucleation of lead carbonate phases and confirmed the secondary dissolution of lead carbonate crystals grown epitaxially from the initial nuclei. The XPS spectra confirmed that adsorption of $\mathrm{Pb}$ occurs simultaneously to dissolution at short interaction times (less than $\mathbf{1 0}$ min, prior to precipitationnucleation/crystal growth) in the case of both $\mathrm{CaCO}_{3}$ polymorphs and that the calcite surface with adsorbed $\mathrm{Pb}$ may have an aragonite-type character. The ${ }^{12} \mathrm{C}$-RBS spectra indicated that absorption (incorporation of $\mathrm{Pb}^{2+}$ ions) also takes place in parallel at the surface layers of the calcium carbonates, resulting in formation of solid solutions.

\section{Introduction}

Although $\mathrm{Pb}$ has been recently classified (along with $\mathrm{As}, \mathrm{Hg}$, $\mathrm{C}_{2} \mathrm{H}_{3} \mathrm{Cl}$, and $\mathrm{C}_{6} \mathrm{H}_{6}$ ) at the top of the priority list of the most hazardous substances, it is still extensively used by modern society (in gasoline, batteries, paints/pigments, pipes/solders, bullets, and insecticides) because it remains cheap and easily available. Research performed during recent decades has indicated that the chemical mobility of $\mathrm{Pb}$ in the geosphere, and furthermore its harmful involvement in the biosphere, taking place mainly through aquatic pathways (surface and underground waters) is strongly correlated to interactions with different geomedia represented by rocks/soils and specifically by their mineral components. The interaction of minerals with $\mathrm{Pb}$ is fundamentally related to different sorption (metal uptake) processes or mechanisms (e.g., refs 1 and 2), known to be a critical factor in controlling the dispersion and accumulation of heavy metals in the environment and their geoavailability and bioavailability. There are several relevant studies in the literature concerning silicates, aluminosilicates, and oxides/oxyhydroxides, but special emphasis has been given to calcium phosphates (apatites), which have also been pro-posed for in-situ $\mathrm{Pb}$ immobilization in aqueous media and contaminated soils (e.g., ref 3). The interaction of calcium phosphates with dissolved $\mathrm{Pb}$ ions is rapid and intense, and the relevant sorption processes (mainly realated to massive surface precipitation) are directly connected to subsequent crystal growth processes (e.g., ref 4) involving the formation of adequately insoluble lead phosphate/ hydroxyphosphate and hydroxycarbonate phases. It has been generally shown that the dissolution of apatite is correlated to precipitation of pyromorphite ( $\mathrm{Pb} 5(\mathrm{PO} 4) 3 \mathrm{X}, \mathrm{X}) \mathrm{Cl}, \mathrm{OH}, \mathrm{F}, \mathrm{Br}$ ) under acidic conditions while hydrocerussite $(\mathrm{Pb} 3(\mathrm{CO} 3) 2(\mathrm{OH}) 2)$ is favored under alkaline conditions. In the case of experiments with apatite powder and aqueous solutions of [Pbaq]initial 5180 $\mathrm{mg} / \mathrm{L}$ using a batch-type procedure $(1.2 \mathrm{~g}$ of apatite in $35 \mathrm{~mL}$ of solution)
It was shown that after 24-h equilibration the removal of $\mathrm{Pb}$ was almost complete at $99.9 \%(151 \mathrm{mg} / \mathrm{g}$ ). More data (for $\left[\mathrm{Pb}_{\mathrm{aq}}\right]_{\text {initial }}$ between 0.5 and $500 \mathrm{mg} / \mathrm{L}$ ) obtained by means of insitu/ex-situ AFM and SEM indicated rounded features on the surface of dissolved apatite with the absence of crystallographically controlled etch pits, whereas the surface precipitation leading to crystal growth of pyromor-phite was attributed to homogeneous nucleation in the case of supersaturated solutions ( $\left[\mathrm{Pb}_{\mathrm{aq}}\right]_{\text {initial }}>100 \mathrm{mg} / \mathrm{L}$ ) and to heterogeneous nucleation in the case of undersaturated solutions ([Pb $\left.\left.]_{\text {aq }}\right]_{\text {initial }}<10 \mathrm{mg} / \mathrm{L}\right)$ (e.g., refs $\left.5-10\right)$.

The physicochemical processes taking place during the interaction of calcium phosphates and $\mathrm{Pb}$ in aqueous solutions are almost identical to those for calcium carbonates. The two common polymorphs of $\mathrm{CaCO}_{3}$, calcite (trigonal) and aragonite (orthorhombic), are among the most abundant minerals on the earth and also have an additional biological importance. Due to the fact that their chemical behavior in respect of $\mathrm{Pb}$ is similar to calcium phosphates they have also been proposed for remediation of $\mathrm{Pb}$-contaminated lands (e.g., ref 11). With regard to the interaction of calcium carbonates with $\mathrm{Pb}$ in aqueous solutions, the literature is restricted as compared to that for calcium phosphates, and most of the work is related to calcite while the data for aragonite are very limited. Moreover, the information already obtained even on the interaction of calcite with $\mathrm{Pb}$ constitutes only a fraction of that available for other metals such as $\mathrm{Mn}, \mathrm{Co}, \mathrm{Zn}$, and $\mathrm{Cd}$, although they are considered (except $\mathrm{Cd}$ ) much less hazardous than $\mathrm{Pb}$. Gamsja"ger et al. (12) referred to the rapid immobilization of $\mathrm{Pb}^{2}$ + ([Pb $\left.]_{\text {aq }}\right]_{\text {initial }}$ between 207 and $\left.2070 \mathrm{mg} / \mathrm{L}\right)$ on calcite and, moreover, on aragonite powders through surface precipitation of cerussite $\left(\mathrm{PbCO}_{3}\right)$. It is notable that the formation of hydrocerussite was not reported. Similar results (without giving information on

* Correspondingauthor phone: +49-251-8333487; fax: +49-2518338397; e-mail: athgod@nwz.uni-muenster.de.

† Universität Münster.

₹ University of Bristol.

$\S$ NRCPS “Demokritos". 
hydrocerussite) were presented only for calcite by Petrovic' et al. (13), who used a batch-type procedure and [Pbaq]initial $2070 \mathrm{mg} / \mathrm{L}$, as well as by Hong et al. (14). Furthermore, it was shown that $\mathrm{Pb}$ is sorbed by heated (aragonite $\mathrm{f}$ calcite) coral sand (15) and that the removal of $\mathrm{Pb}$ from solutions of high [Pbaq]initial $(200-1200 \mathrm{mg} / \mathrm{L})$ by crab shell particles is due to surface precipitation of both cerussite and hydrocerussite (16). An investigation using synchrotron X-ray standing wave and $X$-ray reflectivity techniques as well as AFM of millimeter-sized calcite single crystals interacted with solutions of low [Pbaq]initial $\left(\left\ulcorner 2,-17\right.\right.$, and ${ }^{-} 23 \mathrm{mg} / \mathrm{L}$, complexed with EDTA) was described by Sturchio et al. (17), who concluded that $60 \%$ of the sorbed $\mathrm{Pb}^{2+}$ occupies surface $\mathrm{Ca}^{2+}$ sites. Similar results based on EXAFS data concerning the occupation of 6 -coordinated $\mathrm{Ca}^{2+}$ sites by $\mathrm{Pb}^{2+}$ in the structure of synthetic calcite doped with $\mathrm{Pb}$ impurities $(0.615 \mathrm{mg} / \mathrm{g})$ during its crystal growth and in the structure of natural $\mathrm{Pb}$-bearing $(0.735$ and $6.55 \mathrm{mg} / \mathrm{g})$ calcite were presented by Reeder et al. (18).

The primary objective of the present paper was to refine and reevaluate the existing data (12-16) on the interaction of calcite and aragonite crystals of different sizes with aqueous solutions of high [Pbaq]initial (supersaturated solutions appearing naturally acidic), taking into account the relevant studies on calcium phosphates mentioned above. In particular, we attempted to distinguish the different processes (dissolution, sorption, nucleation/crystal growth) taking place at the calcium carbonate solid-water interface using a combination of wet-chemical, in-situ (AFM) and ex-situ (AFM, SEM) microscopic, and surface spectroscopic (XPS,

${ }^{12} \mathrm{C}$-RBS) techniques. While some in-situ AFM data are available for $\mathrm{Pb}$ sorption on calcite (17), there is no relevant information in the literature concerning aragonite. On the other hand, XPS (and SIMS, LAMMA) results are available only for calcite and low [Pbaq]initial $(-1-10 \mathrm{mg} / \mathrm{L})(19,20)$. While adequate data have already been presented in the case of low [Pbaq]initial (17-20), major questions still remain regarding interaction of calcium carbonates with solutions of high [Pbaq]initial (likely answered for calcium phosphates). Finally, special attention was given to the definition of the processes occurring at the first stages of the interaction as has already been demonstrated for calcite exposed for $1 \mathrm{~min}$ to aqueous solutions of high [Niaq]initial (21).

\section{Experimental Section}

The calcite (CAL) and aragonite (ARA) specimens used in all experiments were pure crystals from Chihuahua, Mexico, and Minglanilla, Spain. The purity of the minerals was confirmed using chemical methods and X-ray diffraction. In the first part of the experiments, characterized samples of micrometer-sized crushed crystals (100-200 im fragments obtained using an agate mortar and Retsch standard analytical sieves) were reacted at room temperature under atmospheric $\mathrm{PCO}_{2}$ with aqueous solutions of $\mathrm{Pb}\left(\mathrm{NO}_{3}\right)_{2}$. The investigation was based on a macroscopic batch-type treat-ment procedure using solutions of [Pbaq]initial between 10 and $1000 \mathrm{mg} / \mathrm{L}$ (pHinitial: 6.80-4.75), 50-mL 30115 $\mathrm{mm}$ sterile PPN Tubes (Greiner Bio-One), and solid-liquid ratio of $0.01 \mathrm{~g} / \mathrm{mL}$ as suggested in previous sorption and dissolution studies (e.g., refs 19 and 22). The interacted calcium carbonates were separated from the suspensions using a Nalgene apparatus and Millipore 0.45 membrane filters, whereas centrifugation was avoided (which causes, according to preliminary experiments, additional precipitation). The filtrates were analyzed by means of ICP-AES (Thermo Jarrell Ash, Atom Scan 25), and the solids were studied by SEM-EDS (JEOL JSM-6300F equipped with a Link EDS) and powderXRD (Philips X'Pert diffractometer, Cu KR radiation). In the second part of the experiments, individual mil-limeter-sized cleaved crystals (rhombohedral and hexagonal prismatic slices of $\mathrm{CAL}$ and $\mathrm{ARA}$, respectively) were prepared by cleaving the initial bigger crystals with proper stainless steel blades. The materials were not chemically pretreated, and the newly cleaved surfaces were in contact with nothing but air before exposure to $\mathrm{Pb}$ solutions. For the in-situ AFM investigation (23-25), suitable crystals were carefully placed into the fluid cell of a D.I. nanoscope III multimode AFM, working in contact mode, and first interacted with distilled water and further with a solution of [Pbaq]initial $1000 \mathrm{mg} / \mathrm{L}$ up to ${ }^{-20} \mathrm{~min}$. The ex-situ AFM investigation was performed directly on the crystals removed from the AFM fluid cell using a D.I. Dimension 3000 AFM working in tapping mode. These crystals were also examined using SEM-EDS and powder-XRD. At the same time to obtain relevant samples for the spectroscopic investigations, similar freshly cleaved crystals were reacted in PPN tubes with solution of [Pbaq]initial $1000 \mathrm{mg} / \mathrm{L}$ for different periods of time $(1,5$, and $20 \mathrm{~min})$. The methodology proposed by Hoffmann and Stipp (21) was generally followed. The crystals were immersed into $\mathrm{Pb}$ solution and held in constant motion for a given period of time by holding two of their edges with Teflon tweezers. At the end of the exposure time, each crystal was removed, and the remaining droplets were blown from the surface using a stream of high-purity $\mathrm{N}_{2}$. Then, the interacted samples were introduced into the vacuum chambers for the spec-troscopic investigations, adjusted carefully in proper stainless steel holders. The XPS investigation was performed using a VG Escascope and $\mathrm{Mg}$ $\mathrm{KR}$ X-rays (charge-correcting the spectra on the basis of the adventitious hydrocarbon $\mathrm{C}$ 1s signal at $284.8 \mathrm{eV}$ ). The ${ }^{12} \mathrm{C}$ RBS investigation was carried out using a $4.5 \mathrm{MV}$ tandem particle accelerator and an $8 \mathrm{MeV}{ }^{12} \mathrm{C}$-beam, and the code RUMP (26) was used for the simulation of recorded spectra. Finally, the same crystals, studied by the above nondestructive techniques, were also examined using SEMEDS and powder-XRD as well as crystals reacted separately with $\mathrm{Pb}$ solution for up to 1 month.

Results and Discussion

CAL and ARA Micrometer-Sized Crystals Interacted with Pb. The experiments on CAL and ARA 100-200 ím fragments using a macroscopic batch-type treatment procedure showed that the removal of $\mathrm{Pb}$ from aqueous solutions of [Pbaq]initial $10 \mathrm{mg} / \mathrm{L}$ is very fast and that the practical end of the sorption process (almost complete removal of the metal) is reached at 1 -min interaction. The results of experiments for solutions of [Pbaq]initial $100 \mathrm{mg} / \mathrm{L}$ and $1000 \mathrm{mg} / \mathrm{L}$ are presented in Figurthe first case the practical end of the sorption process is macroscopically reached at $" 10 \mathrm{~min}$ for both $\mathrm{CAL}$ and ARA, whereas in the second case it is reached at ${ }^{-} 1.5 \mathrm{~h}$ for CAL and at ${ }^{-12} \mathrm{~h}$ for ARA. It is evident that the sorption of $\mathrm{Pb}$ and the dissolution of the calcium carbonate solids (expressed by the Ca release) are processes taking place in parallel until the almost complete removal of the metal. The $\mathrm{pH}$ of the solutions was consequently increased because of dissolution from pHinitial 4.85 up to $\mathrm{pH} 5.45$ in the case of ARA and up to $\mathrm{pH} 6.85$ in the case of CAL. The sorption distribution coefficients $(K d)$ (e.g., ref 27$)$ for [Pbaq]initial $1000 \mathrm{mg} / \mathrm{L}$ as a function of time follow an exponential trend in the case of CAL and a logarithmic one in the case of ARA. Just before the practical end of the sorption process (after that they become almost infinite), they were found to be 9.2 $10^{2}$ and $4.2 \square 10^{2} \mathrm{~mL} / \mathrm{g}$, respectively. For [Pbaq]initial 100 $\mathrm{mg} / \mathrm{L}$ the $K \mathrm{~d}$ values are even higher, reaching values of 8.7 $10^{4}$ and $4.8 \square 10^{4} \mathrm{~mL} / \mathrm{g}$. The above data reveal the high selectivity of calcium carbonates for $\mathrm{Pb}$, which is comparable only with that of calcium phosphates among common inorganic solids and minerals. Additional experiments concerning solutions of variable [Pbaq]initial (10-1000 mg/L) until the almost complete removal of the metal $(\ulcorner 12 \mathrm{~h}$ treatment in all cases) indicated that the Ca released from the solids (in $\mathrm{mg} / \mathrm{g}$ ) plotted versus 
A

$100 \mathrm{mg} / \mathrm{L} \mathrm{Pb}$

$\pm \mathrm{CAL}-\mathrm{Pb} \rightarrow \mathrm{ARA}-\mathrm{Pb} \rightarrow-\mathrm{CAL}-\mathrm{Ca} \leadsto-\mathrm{ARA}-\mathrm{Ca}$

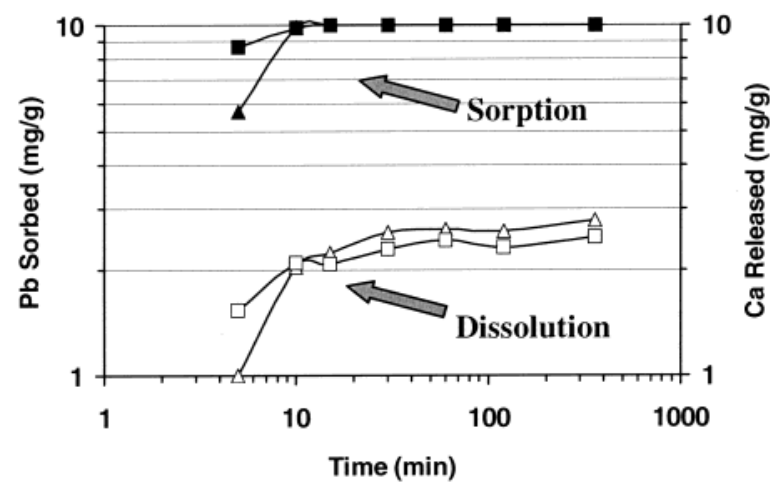

B

$1000 \mathrm{mg} / \mathrm{L} \mathrm{Pb}$

$₫ \mathrm{CAL}-\mathrm{Pb} \rightarrow \mathrm{ARA}-\mathrm{Pb} \quad \triangle \mathrm{CAL}-\mathrm{Ca} \quad \square-\mathrm{ARA}-\mathrm{Ca}$

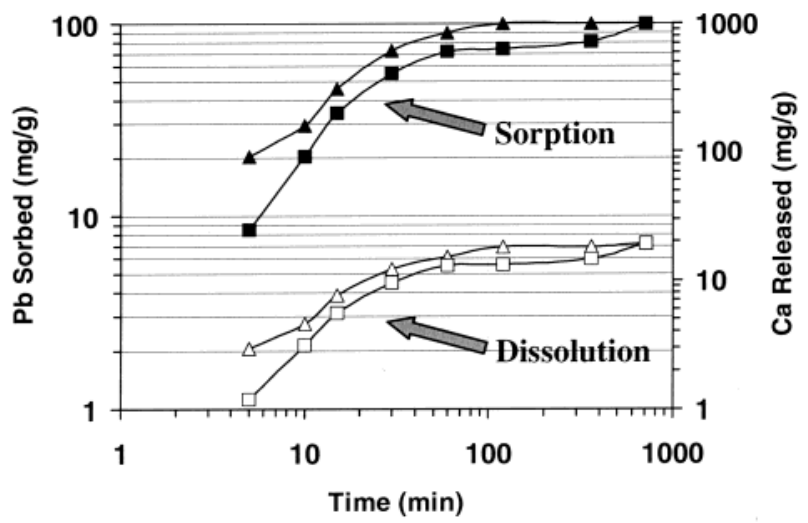

FIGURE 1. Macroscopic analytical data, for the interaction of micrometer-sized CAL and ARA crushed crystals (100-200 ím fragments) with aqueous solutions containing $100 \mathrm{mg} / \mathrm{L}$ (a) and $1000 \mathrm{mg} / \mathrm{L} \mathrm{Pb}$ (b) at room temperature and atmospheric $\mathrm{PCO}_{2}$.

$\mathrm{pH}$ initial values can be described by an inverted sigmoidal-type curve, while it is linearly correlated to [Pbaq]initial values ([Ca] ) 0.0196[Pbaq]initial + 0.3698, $R^{2}$ ) 1). The same conclusion, about a linear increase in Ca concentrations, is illustrated in an unpublished study concerning coarse and fine CAL reacted under atmospheric conditions (28). Besides, it is noted that the relationship is valid also for $\mathrm{Zn}$ but not for $\mathrm{Cd}$ and that $\mathrm{Pb}$ and $\mathrm{Zn}$ reactions are independent of $\mathrm{CaCO} 3$ surface area while those of $\mathrm{Cd}$ are strongly dependent. It can be considered therefore that the dissolution of calcium carbonate fragments/powders in $\mathrm{Pb}$ aqueous solutions is [Pbaq]initial-dependent and subsequently dependent on sorp-tion occurring in parallel.

The investigation by SEM-EDS of all the solid experimental products obtained from the solutions of [Pbaq]initial, 100 and $1000 \mathrm{mg} / \mathrm{L}$, demonstrated that massive surface precipitation leading to growth of lead carbonates takes place after ${ }^{-10}$ min interaction. The lead carbonate crystals appearing in two forms, prismatic acicular and tabular hexagonal, with likely rounded edges, cover a major part of the surfaces of the CAL and ARA fragments and exhibit at certain points typical epitaxial overgrowths. However, detailed powder-XRD study showed that both cerussite and hydrocerussite occur on the surface of CAL but that only cerussite occurs on the surface of ARA. It is known that divalent metal ions such as $\mathrm{Mg}^{2}$ $+, \mathrm{M} \mathrm{n}^{2+}, \mathrm{Fe}^{2+}, \mathrm{Co}^{2+}, \mathrm{Ni}^{2+}, \mathrm{Cu}^{2+}, \mathrm{Zn}^{2+}$, and $\mathrm{Cd}^{2+}$ with ionic radii (29) smaller than that of ${ }^{\prime}[6] \mathrm{Ca}^{2+}$ are 6 -fold coordinated in octahedral sites in the structure of carbonate solids, either as minor or major constituents, and form pure carbonate phases with a trigonal CAL-type structure. However, although $\mathrm{Sr}^{2+}, \mathrm{B} \mathrm{a}^{2+}$, and $\mathrm{Pb}^{2+}$ may occur as minor constituents (impurities) 'in 6-fold coordination (e.g., ref 18), they generally adopt a highers9-foldscoordination as major constituents in phases with an orthorhombic ARA-type structure. In this case, the ionic radii of the divalent 6- and 9coordinated metal ions are larger than those of $[6] \mathrm{Ca}^{2+}$ and $\left.\left.{ }^{[9}\right]_{\mathrm{Ca}^{2+}}\left([6]_{\mathrm{CCa}^{2+}}\right) 1 \AA,[9]_{\mathrm{CCa}^{2+}}\right) 1.18 \AA$ and $\left.{ }^{[6}\right]_{\mathrm{rPb}^{2+}}$ ) $\left.\left.1.19 \AA,{ }^{[9}\right]_{r b^{2}}{ }^{2+}\right) 1.35 \AA$ ). As stated by Zachara et al. (30, 31), $\mathrm{Me}^{2+}$ ions with small ionic radius are preferably sorbed at basic $\mathrm{pH}$ on the surface of powdered $\mathrm{CAL}$ according to the selectivity sequence $\mathrm{Cd}>\mathrm{Zn} \mathrm{g} \mathrm{Mn}>\mathrm{Co}>\mathrm{Ni}$. Ba ) Sr, but they are also easily desorbed due to higher hydration energies. However, although the above work concerned low $\left[\mathrm{Me}^{2+}\right.$ aq]initial (in general $<10 \mathrm{mg} / \mathrm{L}$ ) combined the spectroscopic studies demonstrated, in the case of $\mathrm{Zn}$, the surface precipitation of hydrozincite $\left(\mathrm{Zn} 5(\mathrm{OH})_{6}\left(\mathrm{CO}_{3}\right) 2\right)$. Furthermore, Schosseler et al. (32) argued that at low $\left[\mathrm{Me}^{2+}\right.$ aq]initial the sorption is due to an initial fast adsorption reaction followed by a period of slow removal of ions from solution (absorption) while at higher $\left[\mathrm{Me}^{2+}\right.$ aq]initial surface precipitation occurs resulting in discrete carbonate and hydroxycarbonate phases. It is therefore obvious, in our case, that the intense surface precipitation correlated to crystal growth of cerussite and hydrocerussite was enhanced by the increased [Pbaq]initial and that the slightly acidic conditions contributed to surface dissolution and release of excess $\mathrm{CO}_{3}{ }^{2-}$ ions. Besides, the higher $\mathrm{Pb}$ sorption by CAL fragments over ARA, predomi-nantly through surface precipitation, can hardly be explained taking into account the small difference in their solubility

products (log $\left.K_{S P} \mathrm{CAL}\right)-8.48, \log K_{\mathrm{SP}} \mathrm{ARA}$ ) ) 8.34 ). Although both $\mathrm{CaCO}_{3}$ polymorphs is evident under the experimental conditions used, the association of hydrocerussite solely with $\mathrm{CAL}$ cannot be clearly defined. The available literature concerning the precise characterization of hydrocerussite is confusing because of the existence of similar phases such as plumbonacrite $\left(\mathrm{Pb} 10 \mathrm{O}(\mathrm{OH}) 6\left(\mathrm{CO}_{3}\right) 6\right)$ and due to examination of synthetic nonpurified samples (33). The most reliable early structural data on hydrocerrusite $(33,34)$ have been recently confirmed (35), indicating a layered trigonal $(R 3 \mathrm{hm})$ crystal structure. The arrangement of the structural units in layer $A$ (composed of $\mathrm{Pb}^{2+} / \mathrm{CO}_{3}{ }^{2-}$ and stacked along [001]) is relevant to that of the $\{101 \mathrm{~h} 4\}$ cleavage surface of CAL $\left(\mathrm{Ca}^{2+}\right.$ instead of $\mathrm{Pb}^{2+}$ ), providing evidence for potential structural relationships correlated to epitaxial overgrowths of hydrocerussite onto trigonal CAL and not onto orthorhombic ARA. However, though the above idea could be worth further consideration, it seems that the intense surface precipitation appearing during the interaction of $\mathrm{Me}^{2+}$ ions with calcium carbonates is not simply (mechanistically) related to struc-tural similarities between the new $\mathrm{MeCO}_{3}$ phases and the parent $\mathrm{CaCO}_{3}$ substrate; note that monoclinic $(2 / \mathrm{m})$ hy-drozincite may also overgrow on the surface of CAL. Even for cerussite formed on the surface of ARA, there are critical questions for real structural similarities taking into account that probably cerussite does not have exactly an ARA-type structure (36). In fact surface precipitation and the subse-quent growth of $\mathrm{MeCO} 3$ phases comprise the final visual result of a series of different physicochemical phenomena (dissolution, sorption, and nucleation/crystal growth pro-cesses) taking place at the calcium carbonate solid-water interface. These processes, not completely distinguished by investigating micrometer-sized crystals, have been clarified using millimeter-sized crystals and a combination of wet-chemical, microscopic, and spectroscopic techniques as is demonstrated below.

CAL and ARA Millimeter-Sized Crystals Interacted with Pb. Macroscopic Analytical Study. The chemical data on the 


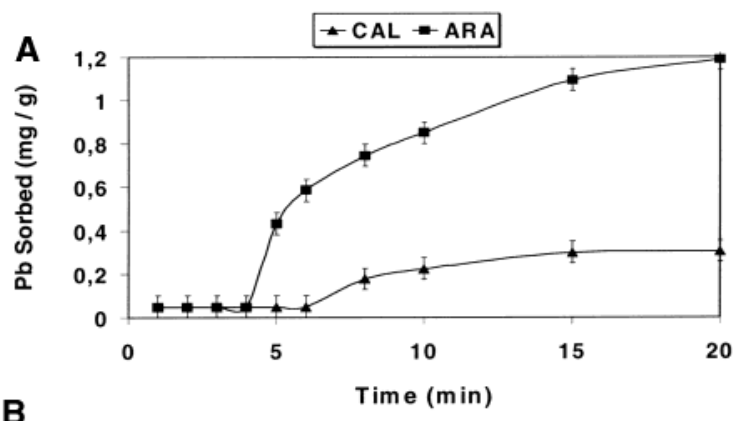

B
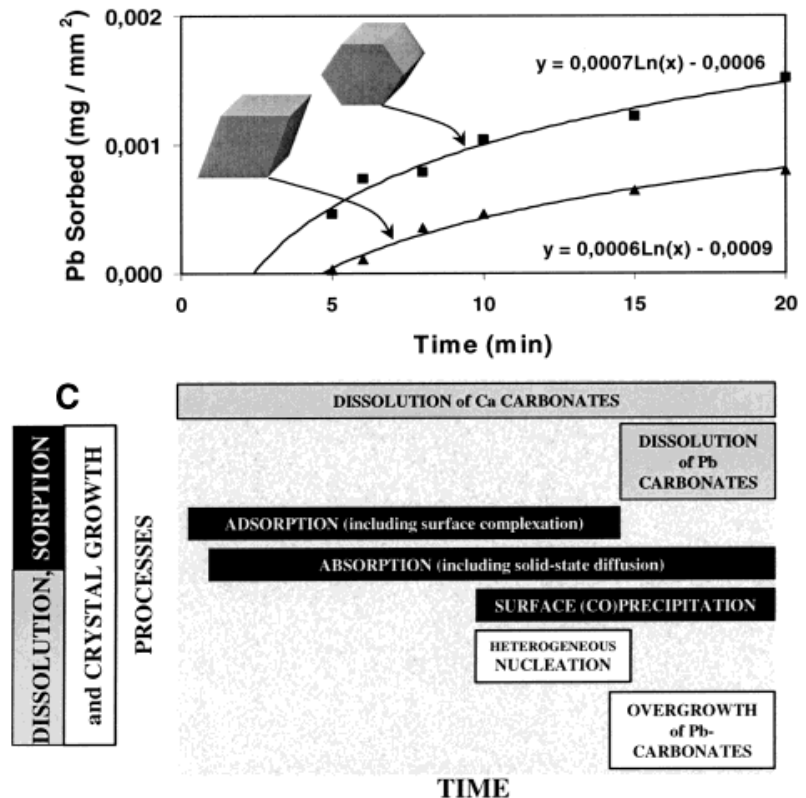

FIGURE 2. Macroscopic data from ICP-AES analyses and optical measurements $(\mathrm{a}, \mathrm{b})$, on the sorption of $\mathrm{Pb}$ from $1000 \mathrm{mg} / \mathrm{L}$ aqueous solutions by individual millimeter-sized CAL and ARA cleaved crystals at room temperature and atmospheric $P_{\mathrm{CO}_{2}}$. An overview of the different sorption processes, taking place in parallel with relevant dissolution and crystal growth processes, is also presented (c) as a basis for further discussion.

interaction of millimeter-sized $\mathrm{CAL}$ and $\mathrm{ARA}$ individual cleaved crystals with solutions of $\left[\mathrm{Pb}_{\mathrm{aq}}\right]_{\text {initial }} 1000 \mathrm{mg} / \mathrm{L}$ are presented in Figure 2a. The interaction of the calcium carbonate materials with $\mathrm{Pb}$ in aqueous solutions was investigated for times up to $20 \mathrm{~min}$, which is equal to the duration of the in-situ AFM experiments (see next section). It is obvious that amounts of $\mathrm{Pb}$ sorbed per mass of the solids (Figure $2 \mathrm{a})$ are considerably lower $(0.30 \mathrm{mg} / \mathrm{g}$ for $\mathrm{CAL}$ and $1.19 \mathrm{mg} / \mathrm{g}$ for ARA) as compared to those recorded for the same period of time in respect of the micrometer-sized materials ( $>50 \mathrm{mg} / \mathrm{g}$ for $\mathrm{CAL}$ and $>40 \mathrm{mg} / \mathrm{g}$ for ARA, see Figure 1). In addition, the $K_{d}$ values are significantly lower $(0.32 \mathrm{~mL} / \mathrm{g}$ for $\mathrm{CAL}$ and $1.23 \mathrm{~mL} / \mathrm{g}$ for $\mathrm{ARA}$ ) indicating that the selectivity of the materials for dissolved $\mathrm{Pb}$ ions is critically decreased by increasing the size of the crystals. This is reasonable considering the greater reactive surface area of the crushed micrometer-sized crystals, which is also correlated to the appearance of several kinds of mechanically induced surface macrodefects such as macrosteps, macrofractures, and broken edges. The observed higher sorption ability of ARA single crystals over CAL, a phenomenon that is opposite in the case of fragments, may also be due to differences in the surface macrotopography (the CAL millimeter-sized crystals are smoother with almost perfect edges) and may not be influenced by their slightly different solubility products. The microtopography of the dissolved surfaces, related to microdefects such as microsteps/kinks, etch pits, and vacancies, is considered to be the same for both micrometer-sized and millimeter-sized crystals. The amounts of $\mathrm{Pb}$ sorbed per mass of the crystals is a useful indicator, but inasmuch as the metal sorption fundamentally concerns the surface of the solids, it is more interesting to present the sorption of $\mathrm{Pb}$ per unit geometric surface area (Figure $2 \mathrm{~b}$ ), which is logarithmically increased during the evolution of the interaction for both CAL and ARA. This also indicates the powerful reactivity of the calcium carbonate surfaces regarding sorption processes taking place at the solid-water interface. However, the different sorption processes, illustrated in Figure $2 \mathrm{c}$ and discussed further in the spectroscopic study section, are absolutely connected to parallel dissolution and nucleation/crystal growth processes as presented in the following paragraphs.

In-situ and Ex-situ Microscopic Study. The results of the insitu AFM investigation of CAL crystals interacted with aqueous solutions of $\left[\mathrm{Pb}_{\text {aq }}\right]_{\text {initial }} 1000 \mathrm{mg} / \mathrm{L}$ are shown in Figure 3a-f. The in-situ AFM is unique in observing and recording directly the dynamic evolution of reacting solid surface structures by monitoring changes in surface microtopography. However, data concerning the interaction of calcium carbonate surfaces with dissolved metal ions are still not extensive (23-25, 37-42), especially for elements of higher atomic weight (heavy metals) with industrial and environmental importance. During preliminary injection of distilled water for ${ }^{-1} \mathrm{~min}$ in the AFM fluid cell, the $\{101 \mathrm{~h} 4\}$ cleavage surface, considered to be a flat $(F)$ crystal face with three nonequivalent PBCs (43), is promptly dissolved; typical etch pits of rhombohedral shape are formed on microterraces (see Figure $3 a$ where a continuous surface feature composed of several microsteps is also evident). These rhombic etch pits contain dissolution microsteps that are not

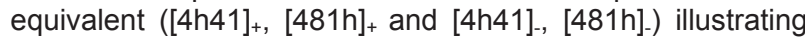
the four step orientations parallel to edges of CAL cleavage face (e.g., ref 44). Analogous positive and negative growth steps, charac-terized by opposite types of kinks $\left([4 \mathrm{~h} 41]_{+/+}\right.$and [4h41]--) along <4h41> also exist at polygonized hillocks that are developed on the $\{101 \mathrm{~h} 4\}$ face of CAL in the presence of trace cations or anions (i.e., impurities). The abovementioned non-equivalence of growth steps is believed to be critical for the preferential incorporation of foreign ions into the structure of CAL during crystal growth. Cations (e.g., $\mathrm{Sr}^{2+}$ and $\mathrm{Pb}^{2+}$ ) and anions (e.g., $\mathrm{SO}_{4}{ }^{2-}$ and $\mathrm{SeO}_{4}{ }^{2-}$ ) that are larger than the potentially substituted structural ions ${ }^{[6]} \mathrm{Ca}^{2}$ ${ }^{+}, \mathrm{C} \mathrm{O}^{2-}$ ) may incorporate in "large" sites located at positive steps, whereas cations that are smaller than ${ }^{[6]} \mathrm{Ca}^{2+}\left(\right.$ e.g., $\mathrm{Mg}^{2}$ ${ }^{+}, \mathrm{M} \mathrm{n}^{2+}, \mathrm{C} \mathrm{O}^{2+}$, and $\mathrm{Cd}^{2+}$ ) tend to incorporate in "small" sites located at negative steps $(45,46)$. Therefore, certain processes have been postulated concerning the interaction of $\mathrm{Pb}^{2+}$ traces with CAL nuclei during crystal growth, leading to $\mathrm{Pb}$-doped $\mathrm{CAL}$ crystals when a solution of low $\left[\mathrm{Pb}_{\mathrm{aq}}\right]_{\text {initial }}$ is added to a growth solution $\left(\mathrm{Ca}^{2+}-\mathrm{NH}_{4}{ }^{+}-\mathrm{Cl}\right)^{-}$. The same processes should also govern the interaction of solutions of low $\left[\mathrm{Pb}_{\mathrm{aq}}\right]_{\text {initial }}$ with preexisting $\mathrm{CAL}$ crystals containing

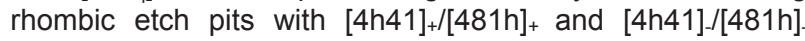
dissolution microsteps on their surface. However, it seems that the processes are still unknown in the case of waterpredissolved $\{101 \mathrm{~h} 4\} \mathrm{CAL}$ surface further interacted with solutions of high $\left[\mathrm{Pb}_{\text {aq }}\right]_{\text {initial. }}$. The in-situ AFM data of the present study demonstrate that the initial rhombic etch pits are rapidly broadened and further transformed to elongated oval etch pits after sub-sequent supply of $1000 \mathrm{mg} / \mathrm{L} \mathrm{Pb}$ solution for ${ }^{-1}$ u p to ${ }^{-10} \mathrm{~min}$ (Figure $3 a-c$ ). The new elongated oval dissolution etch pits are asymmetric with a maximum depth ${ }^{\sim} 22 \AA$ to the left and ${ }^{\sim} 27 \AA$ to the right side. Besides, the height of the microsteps into these etch pits as well as of those separating the new microterraces (showing now a jagged instead of rhombic appearance) is ` $3 \AA$, typical for surface features existing under water. At these $\mathrm{Pb}$ concentrations there may 

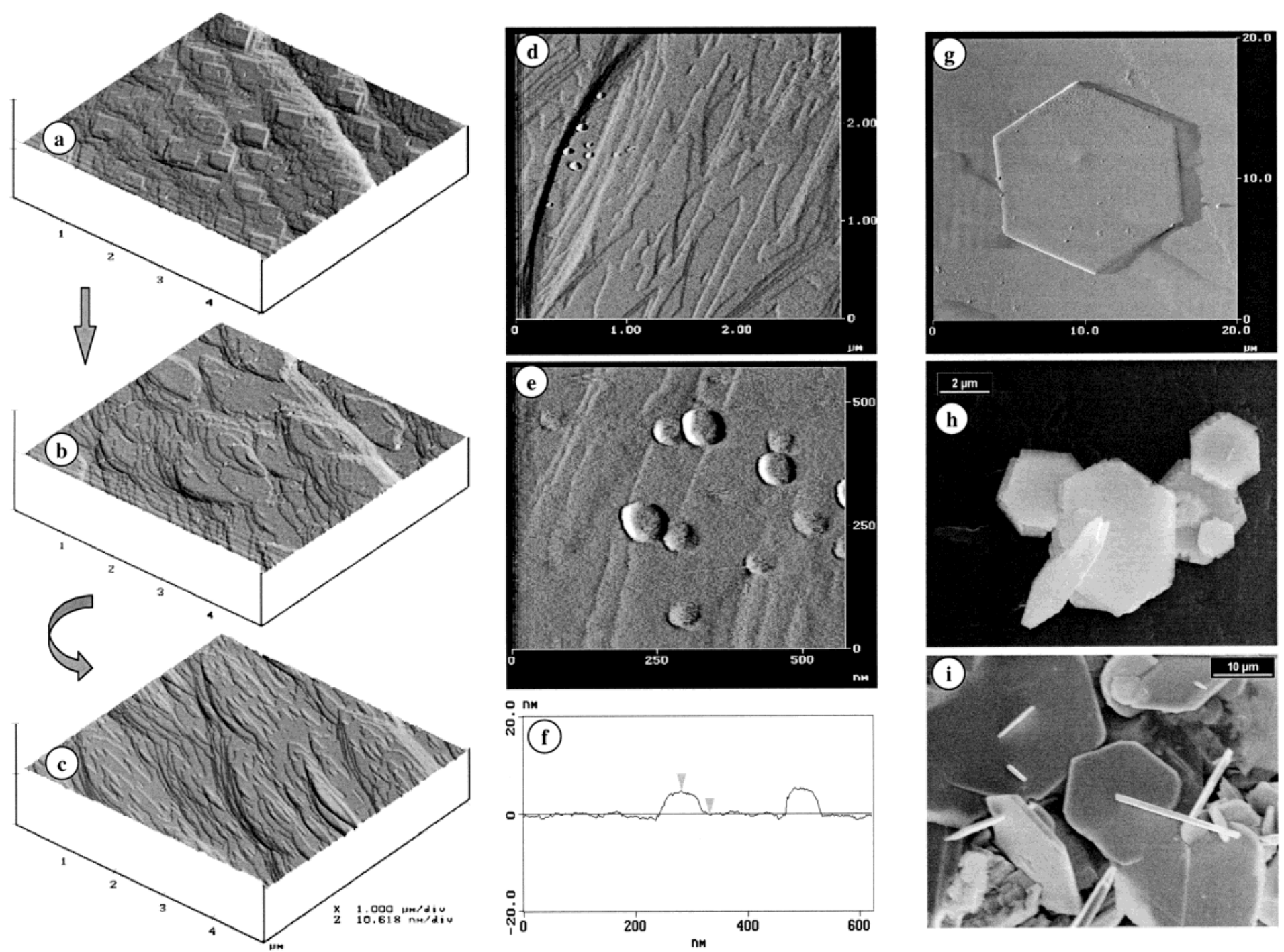

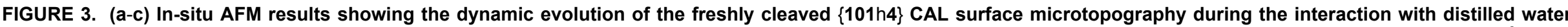

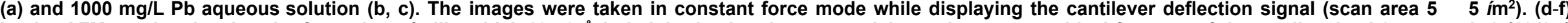

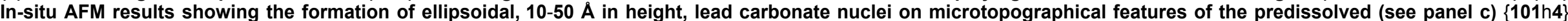

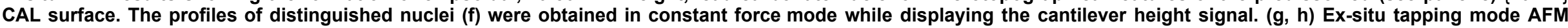

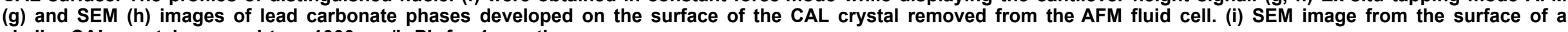
similar CAL crystal exposed to a $1000 \mathrm{mg} / \mathrm{L} \mathrm{Pb}$ for 1 month. 
be no preferential incorporation/sorption of $\mathrm{Pb}^{2+}$ ions in certain surface positions, but most probably $\mathrm{Pb}^{2+}$ ions are adsorbed (bonded to $\mathrm{CO}_{3}{ }^{2-}$ ions) to both "large" and "small" microstep sites in the interior of the initial water-induced etch pits contributing to their transformation through stabilization of [010] step edges at opposite sides of the pit. The same phenomenon has also been observed in the case of anions and particularly for the interaction of CAL with maleic acid, where the formation of oval etch pits through the stabilization of [22h1] is due to the adsorption of the Mal2-ion by pairs of $\mathrm{Ca}^{2+}$ ions into the initial rhombic etch pits (47). After $-10-$ min interaction in the AFM fluid cell, nucleation occurs initially inside the elongated oval etch pits and later onto the neighboring microterraces and specifically at the edges of microsteps (Figure 3d-f). These nuclei possess an ellipsoid shape, and their height varies between 10 and $50 \AA$. This first stage of heterogeneous nucleation leads to growth of lead carbonate crystals and aggregates. The height of the microsteps remains at ${ }^{3} 3 \AA$ during the heterogeneous nucleation process, and there is no increase in the height of the interacted microsteps as has been observed in the case of $\mathrm{Ba}^{2+}(23)$. The crystallization, including the transition from the nuclei to crystals identifiable as lead carbonate crystals, is rather fast and not easy to follow by in-situ AFM. Therefore, in all experiments the CAL single crystals were examined for a total of ${ }^{\circ} 20 \mathrm{~min}$ in the AFM, and then they were removed in order to be examined by ex-situ AFM and SEM-EDS.

The interacted $\{101 \mathrm{~h} 4\}$ cleavage surface of CAL, supporting the newly precipitated lead carbonate crystals, is not morphologically simple and is characterized by areas exhibiting different macrotopography (macroterraces, macrosteps, macrofractures) and microtopography (microterraces, microsteps/kinks). The image shown in Figure $3 g$ was obtained using ex-situ tapping mode AFM, and reveals a rather thin ( $(150 \mathrm{~nm})$ and almost perfect tabular hexagonal crystal of lead carbonate epitaxially overgrown on the $\{101 \mathrm{~h} 4\}$ surface of CAL. On the other hand, SEM images of similar areas indicated thin hexagonal lead carbonate crystals that are not epitaxially overgrown but instead form complex intergrowths on the CAL substrate. The accumulation of lead carbonate crystals at the dissolved edges of the macrosteps as well as of lead carbonate crystals that are systematically arranged parallel to macrofractures was also noted. According to Franke et al. (48), cerussite crystals formed under ambient atmospheric conditions show a typical columnar prismatic habit and only crystals developed at $T$ ) $200{ }^{\circ} \mathrm{C}$ and $P$ ) 1000 bar appear tabular hexagonal. While Pina et al. (49) described, by in-situ AFM, tabular hexagonal cerussite crystals on the (001) dissolved surface of phosgenite. Nevertheless, although a tabular hexagonal habit is expected for hydrocerussite, the wide variety of the cerussite crystal habits in nature indicates that conclusions cannot be based on morphological observations alone. Powder-XRD investigation of material removed from the $\{101 \mathrm{~h} 4\}$ surface of a CAL crystal interacted with $1000 \mathrm{mg} / \mathrm{L} \mathrm{Pb}$ for $20 \mathrm{~min}$, demonstrated the coexistence of cerussite and hydrocerussite. The same conclusion was recorded in a separate experiment using CAL crystals interacted for 1 month with $\mathrm{Pb}$ solution (Figure $3 \mathrm{i}$ ). In this case the $\{101 \mathrm{~h} 4\}$ surface is totally covered by a thick "layer" composed of cerussite and hydrocerussite crystals of different sizes and morphologies. Besides, the SEM image presented in Figure $3 \mathrm{~h}$ reveals an aggregate of hexagonal lead carbonate crystals that have already partly dissolved around the edges. This observation strongly suggests that, as well as the primary dissolution process taking place during the interaction on the surface of calcium carbonates (see above relevant in-situ AFM data), a kind of secondary dissolution occurs after some time on the surface of the newly formed lead carbonate phases.
The above-noted secondary dissolution process was investigated using in-situ AFM during the interaction of millimeter-sized ARA single crystals with a solution of $\left[\mathrm{Pb}_{\mathrm{aq}}\right]_{\text {initial }} 1000 \mathrm{mg} / \mathrm{L}$. In this case, lead carbonate nuclei are also formed on the (001) dissolved surface of ARA, and furthermore almost perfect tabular hexagonal crystals are readily developed, the surfaces of which start immediately to be dissolved. The surface of ARA, in contrast to CAL, exhibits rounded dissolution features with the absence of crystallographically oriented etch pits as has already been observed for calcium phosphates. The in-situ AFM images of Figure $4 a, b$ illustrate such a lead carbonate crystal epitaxially overgrown on ARA, and demonstrate this second-ary dissolution phenomenon. During the AFM experiment, the top and edges of the crystal were progressively dissolved showing large irregular and small trigonal etch pits. The larger etch pit was found to comprise ${ }^{-25 \%}$ of the total crystal

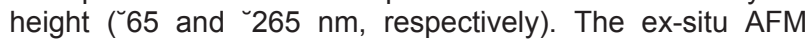
images of the Figures 4c,d indicate an almost perfect tabular hexagonal crystal of lead carbonate epitaxially overgrown on the (010) dissolved surface of the ARA sample removed from the AFM fluid cell as well as two crystals intergrown additionally between them. Note also the twinned "trilling" crystal (partially dissolved) in the SEM image of Figure 4e. The SEM image of Figure $4 \mathrm{f}$ shows lead carbonate crystals developed on ARA after 1 month interaction with $\mathrm{Pb}$, revealing among others a very interesting type of trigonal crystal growth, which could be the subject of further research.

Chemical Behavior and Stability of the Overgrown Lead Carbonates. It is generally considered that the dissolution rates of the common divalent metal carbonates at 5 e pH e 8 increase in the order $\mathrm{Ni}<\mathrm{Mg}<\mathrm{Co}<\mathrm{Fe}<\mathrm{Mn}<\mathrm{Zn}<\mathrm{Cd}<\mathrm{Sr}$ e $\mathrm{Ca}{ }^{\circ} \mathrm{Ba}{ }^{`} \mathrm{~Pb}$ and that cerussite, though

adequately insoluble ( $\left.\log K_{\mathrm{sp}}^{\mathrm{CER}}\right)$ - 13.23), weathers easily to hydrocerussite, which appears to be more stable in nature $(50,51)$. However, from the thermodynamical point of view, the system $\mathrm{Pb}^{2+}-\mathrm{Ca}^{2+}-\mathrm{CO}_{3}{ }^{2-}-\mathrm{H}_{2} \mathrm{O}$ is particularly complex. One reason for such complexity is that several solid phases can occur in the system near ambient temperature and pressure: three polymorphs of $\mathrm{CaCO}_{3}$ (calcite, aragonite, and vaterite), two polymorphs of $\mathrm{PbO}$ (litharge and massicot), and three lead carbonates (cerussite, hydrocerussite, and plumbonacrite). The relative stabilities of the $\mathrm{CaCO}_{3}$ polymorphs are well-known, whereas the $\mathrm{PbO}$ phases and plumbonacrite are thermodynamically stable at very high $\mathrm{pH}$ values $(\mathrm{pH}>12)(52)$.

However, there is no agreement about the relative stability of cerussite and hydrocerussite in an open system. Whereas Bilinski and Schindler (53) concluded that hydrocerussite is the most stable solid phase in natural waters, Taylor and Lopata (52) as well as Mercy et al. (54) stated that hydrocerussite is at all values of $\mathrm{pH}$ more soluble than cerussite, which is therefore thermodynamically more stable. The problem arises because the equilibrium in the reaction $3 \mathrm{PbCO}_{3}(\mathrm{~s})+\mathrm{H}_{2} \mathrm{O}$ a $\mathrm{Pb}(\mathrm{OH})_{2} \hat{\mathrm{a}}\left(\mathrm{PbCO}_{3}\right)_{2}(\mathrm{~s})+\mathrm{CO}_{2}(\mathrm{~g})$ lies very close to the partial pressure of $\mathrm{CO}_{2}$ in the atmosphere $\left.\left(P_{\mathrm{CO}_{2}}\right) 1^{-3.5}\right)$. Consequently, the shift to either cerussite or hydrocerussite is extremely sensitive to the speciation model (for dissolved $\mathrm{Pb}$ ) and Gibbs energy of formation of the solids chosen to interpret the data. All these authors came to the conclusion that, using the best available thermodynamic data, it is impossible to resolve once and for all which of these solids is stable when exposed to atmospheric conditions. However, the situation is different when we consider a solution (with an initial $P_{\mathrm{CO}_{2}}$ ) 10-3.5) closed to exchange of $\mathrm{CO}_{2}(\mathrm{~g})$. In such a case, an increase in $\mathrm{pH}$ leads to a depletion in the $P_{\mathrm{CO}_{2}}$ value and, consequently, hydrocerussite becomes more stable at $\mathrm{pH}>7$. Such a phase can, therefore, be kinetically favored in situations where $\mathrm{a} \mathrm{CaCO}_{3}$ phase is in contact with a solution containing $\mathrm{Pb}$. The dissolution of the 

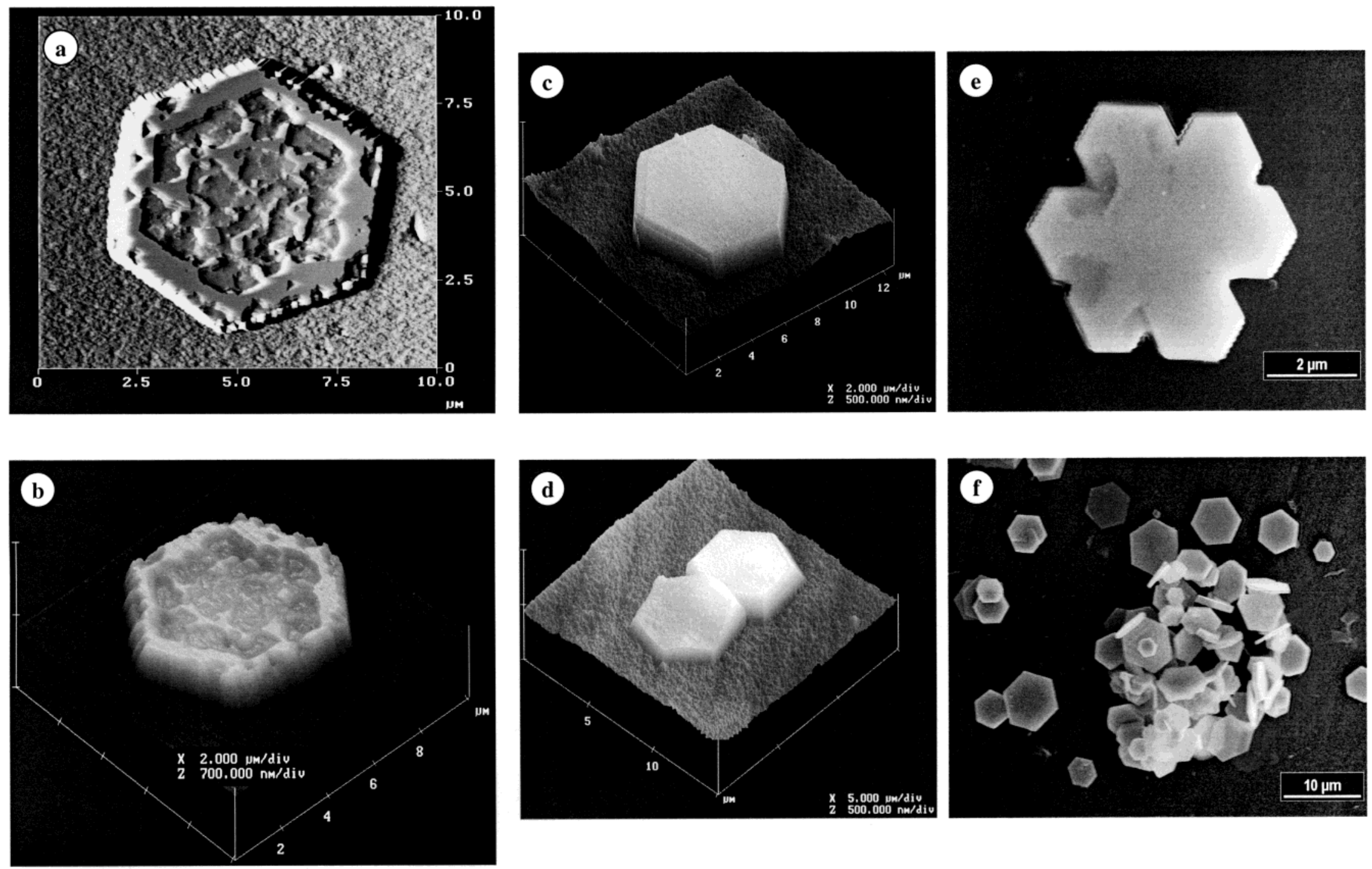

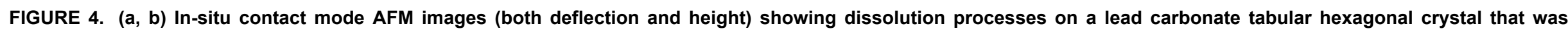
epitaxially overgrown on the dissolved (001) surface of ARA after injection of $1000 \mathrm{mg} / \mathrm{L} \mathrm{Pb}$, (c-e) Ex-situ tapping mode AFM (c,d) and SEM (e) images of lead carbonate phases developed on the surface of the ARA crystal removed from the AFM fluid cell. (f) SEM image from the surface of a similar ARA crystal exposed to a 1000 mg/L $\mathrm{Pb}$ for 1 month. 

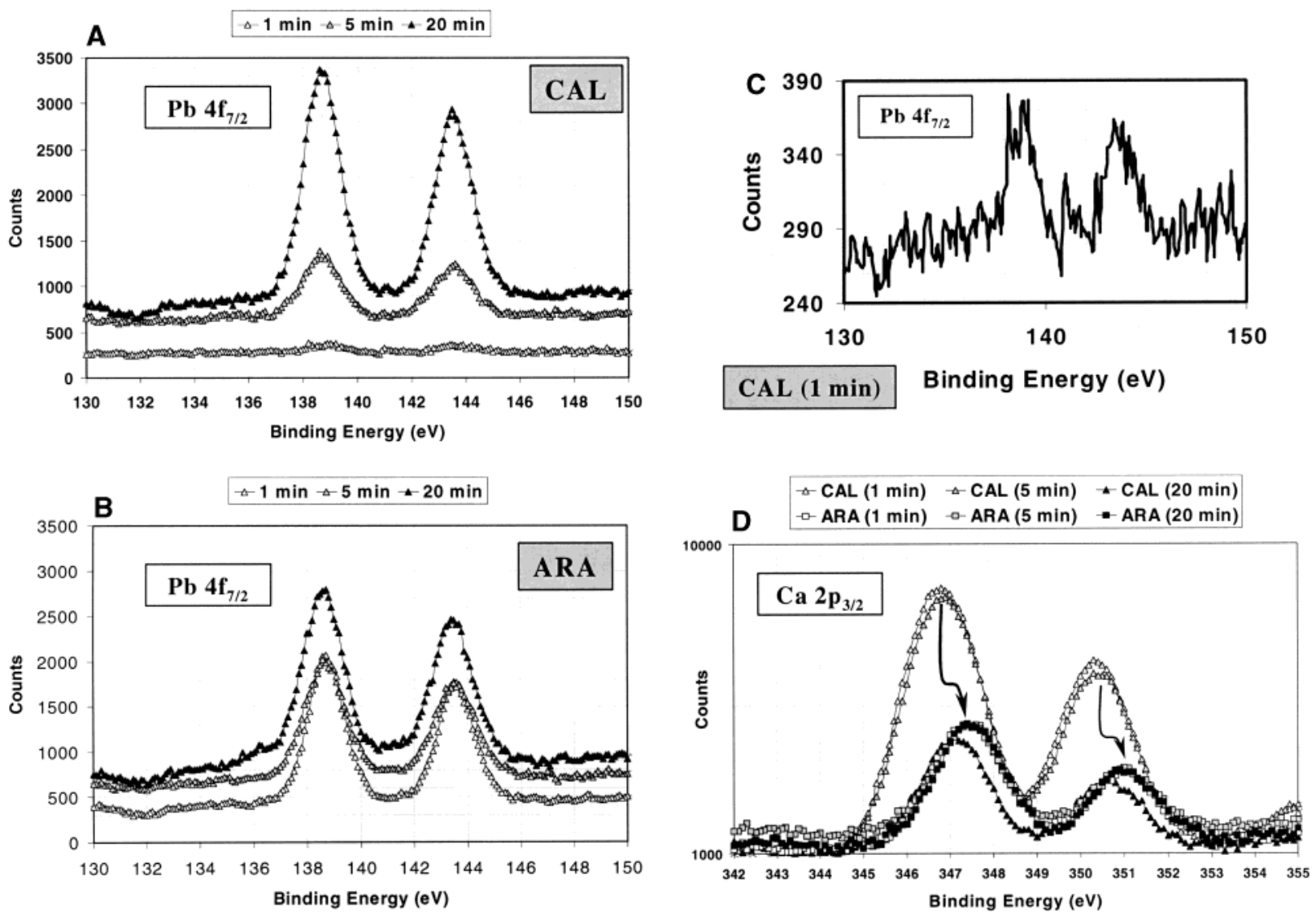

FIGURE 5. XPS data on millimeter-sized CAL and ARA crystals interacted for 1,5 , and 20 min with $1000 \mathrm{mg} / \mathrm{L} \mathrm{Pb}$ at room temperature and atmospheric $\mathrm{PCO}_{2}$.

carbonate phase causes an analogous situation: a locally rapid increment of $\mathrm{pH}$ in the solid-water interface and a decrease in $\left[\mathrm{CO}_{2}\right.$ a q $]$. As a consequence, hydrocerussite can crystallize. A subsequent equilibration with atmospheric $\mathrm{CO}_{2-}$ (g) can lead to a higher stability of cerussite. The powder$X R D$ investigation of material removed from the surface of ARA crystals interacted with $\mathrm{Pb}$ for ${ }^{-20}$ min in the AFM fluid cell, confirming the presence of only hydrocerussite. As has also been noted to the section on the micrometer-sized materials, the surface of the ARA fragments contained only cerussite after virtually complete removal of the metal (720min or 12-h interaction). In addition, the powder-XRD study of ARA single crystals interacted with $1000 \mathrm{mg} / \mathrm{L} \mathrm{Pb}$ for 1 month, indicating the existence of only cerussite. The above data provide evidence that at short-time interaction hydrocerussite is formed on the surface of ARA which is later replaced by cerussite or, most probably, the precursor hydrocerussite is transformed to cerussite. This phase transformation (hydrocerussite $f$ cerussite) as well as the reverse (cerussite $f$ hydrocerussite) are quite likely according to the thermodynamical considerations presented above. The same phenomenon has been noticed in the case of metallic $\mathrm{Pb}$ patination (55), in which the favored reaction scheme is $\mathrm{Pb}$ f PbO f $\mathrm{Pb}_{3}\left(\mathrm{CO}_{3}\right)_{2}(\mathrm{OH})_{2}$ f $\mathrm{PbCO}_{3}$ (further exposure to $\mathrm{SO}_{2}$ causes cerussite to undergo conversion to $\mathrm{PbSO}_{3}$, which is itself then oxidized to $\mathrm{PbSO}_{4}$ ).

Spectroscopic Study and Outline of the Surface Processes. According to the data already cited, it is evident that the dissolution and nucleation/crystal growth processes are quite well-documented and well-defined, but vital questions still remain in respect of the different sorption processes taking place in parallel (see also Figure 2c). In fact, the particular sorption process referred in the literature as surface (co)-precipitation is eventually expressed by nucleation/crystal growth of lead carbonates. Exact information about adsorp- tion (chemical binding of $\mathrm{Pb}^{2+}$ ions onto the dissolved surface) and absorption (incorporation of $\mathrm{Pb}^{2+}$ ions into the surface structure associated to formation of solid solutions) were obtained by means of spectroscopic investigations.

The XPS spectra of CAL and ARA single crystals interacted with solutions of $\left[\mathrm{Pb}_{a q}\right]_{\text {initial }} 1000 \mathrm{mg} / \mathrm{L}$ for 1,5 , and $20 \mathrm{~min}$ are presented in Figure 5 . It is evident that during the first stages of the interaction (1min and even 5 min) adsorption of $\mathrm{Pb}^{2+}$ ions occurs on the surface of calcium carbonates simultaneously with dissolution and before the initiation of any surface precipitation (as noted by in situ AFM for crystals exposed to the same solutions for the same periods of time). The relevant $\mathrm{Pb} 4 \mathrm{f}_{7 / 2}$ photoelectron peaks for both CAL and ARA correspond to binding energies (BE) between 138.6 and $138.8 \mathrm{eV}$, which are characteristic of lead carbonate com-pounds and indicate that $\mathrm{Pb}^{2+}$ ions are bonded to surface $\mathrm{CO}_{3}{ }^{2-}$ ions. Note that the intensity of

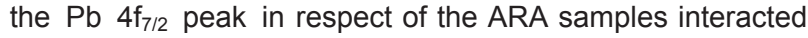
for $1 \mathrm{~min}$ is almost 5.5 times higher than that of CAL (implying intense adsorption). The BE of the spectra concerning 20 min interaction are identical, but the intensities are enhanced because of the overgrown lead carbonates. However, it is rather impossible to distinguish cerussite from hydrocerussite because the $\mathrm{BE}$ of $\mathrm{Pb} 4 \mathrm{f}_{7 / 2}$ for both substances are almost the same (e.g., ref 56). However, the precipitation of $\mathrm{Pb}(\mathrm{OH})_{2}$ and $\mathrm{PbO}\left(\mathrm{Pb} 4 \mathrm{f}_{7 / 2}\right.$ at $\left.137.3 \mathrm{eV}\right)$ can be excluded. It should also be noted that, in the case of CAL interacted for $20 \mathrm{~min}$, the BE of $\mathrm{Ca} 2 \mathrm{p}_{3 / 2}$ is shifted to higher energy $(+0.3 \mathrm{eV})$, which is characteristic of ARA (e.g., ref 57). An analogous shift has been recorded for the $C$ 1s peak due to carbonate $C$ atoms. The $C$ 1s peak due to the so-called adventitious hydrocarbon $C$ atoms is located at $284.8 \mathrm{eV}$ precisely for all the samples. The shift of the Ca peak cannot be accounted for by $\mathrm{Ca}$ in the overgrown lead carbonate crystals and strongly suggests that the nearsurface layers of CAL, existing between the lead carbonate 
crystals, have an ARA-type structure. This is important in order to demonstrate a new type of mineral replacement reaction (a kind of topotaxial reaction) and to explain potential absorption processes. That means that the surface structure of CAL is re-organized to an ARA-type structure in order to accommodate straightforwardly $\mathrm{Pb}^{2+}$ ions after prolonged interaction.

Furthermore, the absorption processes were ultimately confirmed by the RUMP simulation of the ${ }^{12} \mathrm{C}-\mathrm{RBS}$ spectra. As stated by Carroll et al. (58), who studied the interaction of millimeter-sized CAL crystals with $\mathrm{Nd}$, Th, and $\mathrm{U}$ by means of RBS, the shape of the peaks in the spectra is related to the metal depth distribution. Sharp symmetrical peaks indicate a metal-rich very thin film formed onto the surface (adsorp-tion), whereas asymmetrical peaks and broad plateaus reveal a gradual metal incorporation (absorption) and existence of surface solid solutions. This is not valid if sorption is attributed to surface precipitation, leading to partial or full coverage of the surface with new phases. Thus in the case of the CAL and ARA crystals interacted for 5 and $20 \mathrm{~min}$, the ${ }^{12} \mathrm{C}-\mathrm{RBS}$ spectra are not particularly valuable, and the RUMP simulation indicated much higher thicknesses for the $\mathrm{Pb}$ containing surface "layers" due to the contribution of nucleation/crystal growth. However, the spectra are very useful for the samples interacted for $1 \mathrm{~min}$ (prior to crystallization of lead carbon-ates), revealing in the case of CAL the presence of $\mathrm{Pb}$ to a depth of $` 430 \AA$ and to greater depth (up to ${ }^{-2} \mathrm{im}$ ) in the corresponding case of ARA. The absorption (incorporation) or even the spontaneous movement of metal ions, at standard temperature and pressure, within the near-surface structure of CAL through a type of solid-state diffusion mechanism has already been proposed by Stipp et al. $(1,37)$ and Hoffmann and Stipp (21). Additionally, Reeder et al. in a recent presentation (59) indicated that the coordination of $\mathrm{Pb}$ adsorbed via innersphere surface complexation on the external surface of CAL differs from that incorporated in deeper structural Ca sites. However, the above statement regarding incorporated $\mathrm{Pb}^{2+}$ ions in octahedral coordination into the structure of CAL is based on previous EXAFS studies (18), concerning synthetic $\mathrm{Pb}^{2+}$-doped $\mathrm{CAL}$ crystals $(\mathrm{Pb}$ introduced in the lattice during crystal growth) as well as natural $\mathrm{Pb}^{2+}$-bearing $\mathrm{CAL}$ samples. Subsequently, Gaft et al.(60) used laser-induced timeresolved luminescence spec-troscopy to demonstrate that $\mathrm{Pb}^{2+}$ ions must occupy $\mathrm{Ca}^{2+}$ sites in the structure of natural CAL crystals containing $0.45 \mathrm{mg} / \mathrm{g} \mathrm{Pb}$. Moreover, according to Sturchio et al. (17), who studied incorporation of $\mathrm{Pb}$ (though complexed with EDTA) from dilute aqueous solutions, $\mathrm{Pb}^{2+}$ ions may be accom-modated at "rough" surfaces into isolated surface monolayers (hillocks composed by successive microsteps) and at atomi-cally "smooth" surfaces up to the second surface monolayer. Nevertheless, taking into account the roughness of our samples (macrosteps, microsteps) we can also argue that $\mathrm{Pb}^{2+}$ ions are absorbed after short interaction times at least up to the second surface monolayer of CAL, considering the recorded small but well-defined ${ }^{12} \mathrm{C}$-RBS asymmetrical $\mathrm{Pb}$ peaks and the relevant simulation. On the basis of a more optimistic evaluation of the spectroscopic data, the deeper absorption through a solid-state diffusion mechanism, to a depth of several surface monolayers cannot be excluded. As a consequence, $\mathrm{Pb}^{2+}$ ions may substitute ${ }^{[6]} \mathrm{Ca}^{2+}$ ions in $\mathrm{CAL}$, and interstitial solid solutions may be formed. On the other hand, in the case of $\mathrm{ARA}, \mathrm{Pb}^{2+}$ ions can fundamentally more easily substitute ${ }^{[9]} \mathrm{Ca}^{2+}$ ions even to a greater depth toward the formation of typical substitutional solid solutions (the asymmetrical $\mathrm{Pb}$ peaks were found to be at least 30 times higher than those of CAL). Taking into account the ${ }^{12} \mathrm{C}-\mathrm{RBS}$ data, it is moreover concluded that the $\mathrm{Pb}$ diffusion $\left(D_{\mathrm{Pb}}\right)$ in the surface layers of CAL and ARA interacted for a short time with acidic $\mathrm{Pb}$ solution is significantly higher $\left(0.7 \times 10^{-16}\right.$ and $1.8 \times 10^{-16} \mathrm{~m}^{2} / \mathrm{s}$, respectively) as compared to that (1.41 $\times 10^{-21}-6.76 \times 10^{-21} \mathrm{~m}^{2} / \mathrm{s}$ ) observed by Cherniak (61), also using RBS, regarding CAL crystals heated together with a $\mathrm{PbO}$ powder at $445-650^{\circ} \mathrm{C}$ under dry conditions. The most reasonable explanation for this difference is that the presence of water (and particularly to $\mathrm{H}^{+}$ions/protons) alters the entire surface structure through dissolution processes. Thus absorption (and adsorption) of $\mathrm{Pb}$ occur while the surface is dissolving, enhanced by the appearance of dissolutioninduced surface microdefects (vacancies, etch pits, microfractures). On the other hand, the presence of additional surface macrodefects (macrofractures/cracks) could be a supplementary explanation for the rather deep apparent penetration of $\mathrm{Pb}$. Finally, taking all the spectroscopic data into account demonstrates that the solid surface of calcium carbonates and especially of the ARA crystals can act as an efficient scavenger of $\mathrm{Pb}$ during the interaction with aqueous toxic concentrations of the metal.

\section{Acknowledgments}

We would like to thank the European Commission for support within the framework of the European Research Training Network on "Quantifying Dissolution and Precipitation of Solid-Solutions in Natural and Industrial Processes" (Contract HPRN-CT-2000-00058) and the Marie Curie Fellowships Programme. We also acknowledge the support of the European Community Access to Research Infrastructure Action of the Improving Human Potential Programme (Contract HPRI-CT-1999-00008 awarded to Prof. B. J. Wood, EU Geochemical Facility, University of Bristol). Many thanks are finally due to V. Rapelius, U. Breit, and A. Breit (Institut für Mineralogie, Universita"t M"unster) for collaboration during the ICP-AES, SEM-EDS, and powder-XRD investigations.

\section{Literature Cited}

(1) Stipp, S. L.; Hochella, M. F.; Parks, G. A.; Leckie, J. O. Geochim Cosmochim. Acta 1992, 56, 1941-1954.

(2) Manceau, A.; Schlegel, M.; Nagy, K. L.; Charlet, L. J. Colloid Interface Sci. 1999, 220, 181-197.

(3) Traina, S. J.; Laperche, V. Proc. Natl. Acad. Sci. U.S.A. 1999, 96, 3365-3371.

(4) Davey, R.; Garside, J. From Molecules to Crystallizers. An Introduction to Crystallization; Oxford University Press: Oxford, 2000.

(5) Ma, Q. Y.; Traina, S. J.; Logan, T. J. Environ. Sci. Technol. 1993, 27, 1803-1810.

(6) Ruby, M. V.; Davis, A.; Nicholson, A. Environ. Sci. Technol. 1994, 28, 646-654.

(7) Ma, Q. Y.; Logan, T. J.; Traina. S. J. Environ. Sci. Technol. 1995, 29, 1118-1126.

(8) Chen, X.; Wright, J. V.; Conca, J. L.; Peurrung, L. M. Environ. Sci. Technol. 1997, 31, 624-631.

(9) Lower, S. K.; Maurice, P. A.; Traina, S. J.; Carlson, E. H. Am. Mineral. 1998, 83, 147-158

(10) Lower, S. K.; Maurice, P. A.; Traina, S. J. Geochim. Cosmochim. Acta 1998, 62, 1773-1780.

(11) Chen, Z. S.; Lee, G. J.; Liu, J. C. Chemosphere 2000, 41, 235-242.

(12) Gamsja"ger, H.; Fluch, A.; Swinehart, J. H. Monatsh. Chem. 1984, $115,251-259$

(13) Petrovic', M.; Kaštelan-Macan, M.; Horvat, J. M. Water Air Soil Pollut. 1999, 111, 41 -56.

(14) Hong, S. C.; Kim, M. S.; Chung, J. G. J. Ind. Eng. Chem. 2002, 8 (4), 305-312.

(15) Suzuki, Y.; Takeuchi, Y. J. Chem. Eng. Jpn. 1994, 27, 165-170.

(16) Lee, M.-Y.; Park, J. M.; Yang, J.-W. Process Biochem. 1997, 32, 671-677.

(17) Sturchio, N. C.; Chiarello, R. P.; Cheng, L.; Lyman, P. F.; Bedzyk M. J.; Qian, Y.; You, H.; Yee, D.; Geissbuhler, P.; Sorensen, L. B.; Liang, Y.; Baer, D. R. Geochim. Cosmochim. Acta 1997, 61, 251263

(18) Reeder, R. J.; Lamble, G. M.; Northrup, P. A. Am. Mineral. 1999, 84, 1049-1060.

(19) Fulghum, J. E.; Bryan, S. R.; Linton, R. W.; Bauer, C. F.; Griffis, D. P. Environ. Sci. Technol. 1988, 22, 463-467.

(20) Wouters, L. C.; Van Grieken, R. E.; Linton, R. W.; Bauer, C. F. Anal. Chem. 1988, 60, 2218-2220. 
(21) Hoffmann, U.; Stipp, S. L. S. Geochim. Cosmochim. Acta 2001, 65, 4131-4139.

(22) Pokrovsky, O. S.; Mielczarski, J. A.; Barres, O.; Schott, J. Langmuir 2000, 16, 2677-2688.

(23) Astilleros, J. M.; Pina, C.; Ferna'ndez-Dı'az, L.; Putnis, A. Geochim. Cosmochim. Acta 2000, 64, 2965-2972.

(24) Astilleros, J. M.; Pina, C.; Ferna'ndez-Dı'az, L.; Putnis, A. Geochim. Cosmochim. Acta 2002, 66, 3177-3189.

(25) Astilleros, J. M.; Pina, C.; Ferna'ndez-Dı'az, L.; Putnis, A. Chem. Geol. 2003, 193, 93 -107.

(26) Doolittle, L. R. Nucl. Instrum. Methods 1985, B9, 227-235.(27)

Jenne, E. A., Ed. Adsorption of Metals by Geomedia. Variables, Mechanisms, and Model Applications; Academic Press: New York, 1998.

(28) Awada, S. M. The Interaction of $\mathrm{Pb}, \mathrm{Zn}$, and $\mathrm{Cd}$ with Calcite and Millville Silt Loam Soil. Ph.D. Thesis, Utah State University, 1995.

(29) Shannon, R. D. Acta Crystallogr. 1976, A32, 751-767.

(30) Zachara, J. M.; Kittrick, J. A.; Dake, L. S.; Harsh, J. B. Geochim. Cosmochim. Acta 1989, 53, 9 -19.

(31) Zachara, J. M.; Cowan, C. E.; Resch, C. T. Geochim. Cosmochim. Acta 1991, 55, 1549-1562.

(32) Schosseler, P. M.; Wehrli, B.; Schweiger, A. Geochim. Cosmochim. Acta 1999, 63, 1955-1967.

(33) Olby, J. K. J. Inorg. Nucl. Chem. 1966, 28, 2507-2512.

(34) Kokkoros, P.; Vassiliadis, K. Tschermaks Mineral. Petrogr. Mitt. 1953, 3, 298-304

(35) Martinetto, P.; Anne, M.; Dooryhe'e, E.; Walter, P.; Tsoucaris, G. Acta Crystallogr. 2002, C58, i82-i84.

(36) Durman, R.; Jayasooriya, U. P.; Kettle, S. F. A. J. Chem. Soc. Chem. Commun. 1985, 916-917.

(37) Stipp, S. L. S.; Konnerup-Madsen, J.; Franzreb, K.; Kulik, A.; Mathieu, H. J. Nature 1998, 396, 356-359.

(38) Davis, K. J.; Dove, P. M.; De Yoreo, J. J. Science 2000, 290, 11341137.

(39) Shiraki, R.; Rock, P. A.; Casey, W. H. Aquat. Geochem. 2000, 6, 87-108.

(40) Lea, A. S.; Amonette, J. E.; Baer, D. R.; Liang, Y.; Colton, N. G. Geochim. Cosmochim. Acta 2001, 65, 369-379.

(41) Kamiya, N.; Kagi, H.; Notsu, K.; Tsumo, H.; Akagi, T. Chem. Lett. 2002, 890-891.

(42) Stipp, S. L. S.; Lakshatov, L. Z.; Jensen, J. Z.; Buker, J. A. J. Contam. Hydrol. 2003, 61, $33-43$.
(43) Heijnen, W. M. M. Neues Jahrb. Mineral., Monatsh. 1985, H8, 357-371.

(44) Hillner, P. E.; Gratz, A. J.; Manne, S.; Hansma, P. K. Geology 1992, 20, 359-362.

(45) Staudt, W. J.; Reeder, R. J.; Schoonen, M. A. A. Geochim Cosmochim. Acta 1994, 58, 2087-2098.

(46) Paquette, J.; Reeder, R. J. Geochim. Cosmochim. Acta 1995, 59, 735-749.

(47) Hong, Q.; Sua'rez, M. F.; Coles, B. A.; Compton, R. C. J. Phys. Chem. B 1997, 101, 5557-5564.

(48) Franke, W.; Lenk, K.; Ittyachen, M. A.; Pillai, M. K. J. Cryst. Growth 1981, 51, 309-313.

(49) Pina, C. M.; Ferna'ndez-Dı'az, L.; Prieto, M.; Putnis, A. Geochim Cosmochim. Acta 2000, 64, 215-221.

(50) Pokrovsky, O. S.; Schott, J. Environ. Sci. Technol. 2002, 36, 426432.

(51) Grauer, R. Solubility Products of M(II)-Carbonates; PSI: Bericht, 1999; No. 99-04.

(52) Taylor, P.; Lopata, V. J. Can. J. Chem. 1984, 62, 395-402.

(53) Bilinski, H.; Schindler, P. Geochim. Cosmochim. Acta 1982, 46, 921-928.

(54) Mercy, M. A.; Rock, P. A.; Casey, W. H.; Mokarram, M. H. Am. Mineral. 1998, 83, 739-745

(55) Black, L.; Allen, G. C. Br. Corros. J. 1999, 34, 192-197.

(56) Pederson, L. R. J. Electron Spectrosc. Relat. Phenom. 1982, 28, 203-209.

(57) Gopinath, C. S.; Hegde, S. G.; Ramaswamy, V.; Mahapatra, S. Mater. Res. Bull. 2002, 37 (7), 1323-1332.

(58) Carroll, S. A.; Bruno, J.; Petit, J-.C.; Dran, J.-C. Radiochim. Acta 1992, 58/59, 245-252.

(59) Reeder, R. J.; Elzinga, E. J.; Rouff, A. Geochim. Cosmochim. Acta 2002, 66 (Suppl. 1), A628.

(60) Gaft, M.; Seigel, H.; Panczer, G.; Reisfeld, R. Eur. J. Mineral 2002, 14, 1041-1048.

(61) Cherniak, D. J. Geochim. Cosmochim. Acta 1997, 61, 41734179 . 